\title{
Multivariate optimization and evaluation of quaternary mixture in bulk and co- formulated dosage forms by central composite design
}

\author{
Rama Tulasi Jampana ${ }^{*^{*}}$ (D), Prameela Rani Avula ${ }^{1}$ and Panikumar Durga Anumolu²
}

\begin{abstract}
Background: The current study describes the use of central composite design for multivariate optimization of resolution and retention time, taking into account different critical method parameters like organic phase, pH, flow rate, and wavelength for risk assessment. The chromatographic method for the assay of the most effective anti-viral regimen (EPCLUSA, DARVONI, and HARVONI) was developed. An experimental design was presented by sequential investigation of four independent parameters. The method was developed using XTERRA C18 ( $250 \mathrm{~mm} \times 4.6 \mathrm{~mm}$, $5 \mu \mathrm{m}$ particle size) column in isocratic mode using potassium dihydrogen phosphate buffer (pH adjusted to 5) and acetonitrile $(50: 50 \% \mathrm{v} / \mathrm{v})$ as mobile phase at a flow rate of $1.0 \mathrm{ml} / \mathrm{min}$ and $\mathrm{UV}$ detection wavelength of $260 \mathrm{~nm}$.
\end{abstract}

Results: The separation of four drugs with fine resolution and preferable retention times was achieved. Retention times of four drugs were found to be 2.96, 3.91, 7.15, and 11.94 min for daclatasvir, sofosbuvir, velpatasvir, and ledipasvir, respectively. The percentage accuracy of labelled claim was in the range of $99-102 \%$, and the pooled $\%$ RSD for repeatability, precision, and accuracy was less than $2 \%$.

Conclusion: The suggested method was applied for quantification and identification of studied drugs in tablets; the results agreed with the label claim and were validated according to the $\mathrm{ICH}$ guidelines. The optimized method can be used for pharmacokinetic and quality control studies.

Keywords: AQbD, HPLC, Sofosbuvir, Velpatasvir, Ledipasvir, Daclatasvir, EPCLUSA, DARVONI, HARVONI, Anti-viral drugs

\section{Background}

The fast-developing resistance to anti-viral drugs due to rapid viral cell mutation in HIV and hepatitis $C$ virus has garnered researchers worldwide to focus on combination therapy and in analysing the efficacy and toxicity of drugs that act on different targets. Over the past two decades, the researchers worked immensely to identify new molecular targets (structural and non-structural proteins), and trials were still going on to develop drugs

\footnotetext{
* Correspondence: tulasikanumuri@gmail.com

'University College of Pharmaceutical Sciences, Acharya Nagarjuna University, Guntur, Andhra Pradesh 522510, India

Full list of author information is available at the end of the article
}

which were selectively toxic to viruses without causing harm to the host cell. Researchers also aided in improving the efficacy of study by developing HCV replicon cell culture lines for pharmacokinetic and clinical investigations. Despite all the advancements, the anti-viral drug research was still running at a slower pace than expected, so it is the due responsibility of the analytical chemist to develop a method for simultaneous estimation of anti-viral drugs in clinical samples and dosage forms, to make the analysis of drug cost-effective, timesaving, and efficient to demarcate the toxic and therapeutic doses of drugs. The complexity involved in the analysis of effective anti-viral treatment regimen was 
eased by developing a single simple, robust, and selective analytical method for simultaneous assessment of antiviral drugs such as sofosbuvir, velpatasvir, ledipasvir, and daclatasvir using quality-based drug design principles.

$\mathrm{HCV}$ therapy was initially started using a combination of pegylated interferon and ribavarin drugs, until protease inhibitors boceprevir and telaprevir were identified as potent targeted therapies. Later, the advancement in diagnostic tools and molecular target discovery (NS5A, NS5B, and NS3/4A) brought to light drugs like simprevir. But the intense results in therapy were noticed only after the discovery of sofosbuvir. This potent molecule was now available in combination with different drugs such as velpatasvir, daclatasvir, and ledipasvir to treat hepatitis [1-3].

Sofosbuvir is a crystalline solid substance, white to offwhite in colour, and named as "(S)-Isopropyl, 2-((S)-(((2R, 3R,4R,5R)-5-(2,4-dioxo-3,4-dihydropyri-midin-1(2H)-yl)-4fluoro-3-hydroxy-4-methyl tetra hydrofuran-2-yl)methoxy)(phenoxy) phosphorylamino) propanoate". It inhibits the synthesis of RNA by targeting the NS5B polymerase protein of hepatitis $\mathrm{C}$ virus. Sofosbuvir is co-formulated in many multi-drug anti-viral formulations due to its high tolerance to resistance [4].

Ledipasvir named as "(2S)-1-[(6S)-6-[5-(9,9-difluoro-7\{2-[(1R,3S,4S)-2-[(2S)-2\{[hydroxyl(methoxy)methylidene]amino\}-3-ethylbutanoyl]-2-azabicyclo[2.2.1] heptan3-yl]-1H-1,3-benzodiazol-6-yl\}-9H-fluoren-2-yl)-1H-imidazol-2-yl]-5-azaspiro[2.4]heptan-5-yl]-2-\{[hydroxy(methoxy) methylidene]amino\}-3-methylbutan-1-one" is an inhibitor of the NS5A protein of hepatitis $\mathrm{C}$ virus $(\mathrm{HCV})$ which plays a major role in the assembly of $\mathrm{HCV}$ virions and viral RNA replication [5].

Velpatasvir is a white solid substance and chemically known as "(2S)-2-\{[hydroxyl (methoxy) methylidene] amino\}-1-[(2S,5S)-2-(17-\{2-[(2S,4S)-1-[(2R)-2-\{[hydroxyl (methoxy) methylidene] amino\}-2-phenylacetyl]-4-(methoxymethyl)pyrrolidin-2-yl]-1H-imidazol-5-yl\}-21-oxa-5,7diazapentacyclohenicosa-1(13),2,4(8),6,9,11,14(19),15,17nonaen-6-yl)-5-methyl pyrrolidin-1-yl]-3-methylbutan-1one". The drug inhibits viral replication by competing with RNA to bind at domain I of NS5A consisting of amino acids $[6,7]$.

Daclatasvir is beige to white powdery substance and chemically known as "methyl $N-[(2 S)-1-[(2 S)-2-[5-(4$ ' - $\{2-$ [(2S)-1-[(2S)-2-[(methoxycarbonyl) amino]-3-methylbutanoyl]pyrrolidin-2-yl]-1H-imidazol-5-yl\}-[1,1'-biphenyl]-4yl)-1H-imidazol-2-yl]pyrrolidin-1-yl]-3-methyl-1-oxobutan-2-yl]carbamate" and functions by disrupting the hyper-phosphorylated NS5A proteins, thus interferes with new HCV replication complexes function [8].

Quality by design (QbD) helps in understanding and monitoring the process based on quality risk management and sound science [9]. This method also offers a good regulatory flexibility compared to normal one factor at a time (OFAT) experiments [10]. QbD provides information about significant parameters of the method and their interactions in a broader prospect $[11,12]$. It helps to create a method operable design region which eases the work of the analytical chemist and regulatory bodies [13-15]. It also reduces the cost, analysis time, and the number of experimental trials $[16,17]$. The quality of HPLC methods has become increasingly important in a QbD environment $[18,19]$. Thorough literature studies indicated the availability of methods for the analysis of drugs individually or as a combination in a binary mixture, plasma or dosage form, but to date, no analytical method was tried to assay this quaternary mixture in bulk or dosage forms [20-26]. Thus, this article portrays important concepts, such as central composite design to analyse the four anti-viral drugs, i.e. sofosbuvir, velpatasvir, ledipasvir, and daclatasvir by RP-HPLC.

\section{Methods \\ Chemicals and apparatus}

The Shimadzu HPLC (Detector model: SPD20A, Pump model: LC-20 AD) with a UV-visible detector was used for the method development and quantification. LC solutions software was used for processing and monitoring the output signal. The chromatographic column XTERRA RP-18 $(250 \mathrm{~mm} \times 4.6 \mathrm{~mm}, 5 \mu \mathrm{m})$, rheodyne syringe loading manual sample injector $(20 \mu \mathrm{l})$ was used for the analysis of drugs. The design used for the analysis of LC experiments was the Sigma Tech analytical QbD software. Shimadzu AUX 220 model analytical balance, Elico $\mathrm{pH}$ meter, and REMI model Centrifuge were utilized for this work. API (sofosbuvir, velpatasvir, ledipasvir, and daclatasvir) were obtained as a gift sample from Hetero Drugs Private Limited. Analytical grade potassium dihydrogen orthophosphate, sodium hydroxide, potassium hydroxide, di-sodium hydrogen orthophosphate, HPLC grade acetonitrile, and methanol were acquired from Merck, Mumbai. Pharmaceutical tablet dosage forms such as ECLUPSA, HARVONI, and DARVONI were procured from local pharmacies.

\section{Preparation of mobile phase}

Acetonitrile and potassium dihydrogen phosphate buffer, $\mathrm{pH}$ adjusted to 5.0, was taken in the ratio of 50:50 \% v/v and filtered through a $0.45-\mu \mathrm{m}$ membrane filter and sonicated to degas. Acetonitrile and water in the ratio of 50: $50 \% \mathrm{v} / \mathrm{v}$ were used as diluents.

\section{Preparation of standard solution}

Ten milligrams of each standard drug was accurately weighed and transferred into four different $10-\mathrm{ml}$ volumetric flasks, followed by the addition of $7 \mathrm{ml}$ diluent to dissolve. The solution was then sonicated for $15 \mathrm{~min}$ and 
diluted to the mark with diluent to prepare a $1000-\mu \mathrm{g} /$ $\mathrm{ml}$ concentrated solution.

\section{Chromatographic conditions}

In order to study the effect of controlled input factors on responses, they were systematically varied in an experimental design known as "design of experiment" (DOE). DOE was twofold and comprises screening and optimization carried out sequentially [27]. Screening focuses on discriminating the critical method parameters using screening designs such as two-level full or fractional factorial designs in most cases. These designs screen the method parameters that have the ability to affect the analytical method response. The full and fractional design will explore many parameters by setting each on two levels, i.e. higher and lower. Its conclusion helps in identifying the most significant parameters among many others that were involved in the design.

Four variables were selected with their lower and upper values, using the Sigmatech software for screening, and 16 experimental trials were obtained. Based on the results, some of the variables were selected and fixed for the optimization. The selected significant factors are further studied using more comprehensive designs to set the most influential factors at levels that enhance analytical CQAs simultaneously. It provides a base for scientific understanding of the relation between quantities of input variables (CMP) and output response which will show a considerable effect on the method performance and ATP $[17,19]$. The central composite design was utilized to determine the significant variables and optimize the chromatographic conditions with the lowest number of runs. From the screening results, wavelength and organic phases were fixed as dependent variables, and $\%$ of organic phase, aqueous phase $\mathrm{pH}$, and flow rate were selected as variables for optimization with its lower and upper values reported in Table 1. These variables were placed in the Sigmatech software, and 8 experimental trials were obtained. Based on the results, a method was developed with the optimized conditions. The chromatographic trials suggested by the system were performed using Shimadzu HPLC with XTERRA RP $18(250 \mathrm{~mm} \times 4.6 \mathrm{~mm} \times 5 \mu)$ column at UV detection wavelength $260 \mathrm{~nm}$.

Table 1 Variables for optimization with its upper and lower values (qualitative)

\begin{tabular}{llllll}
\hline S.No & Variable & Variable name & Units & Low value & High value \\
\hline 1 & $X_{1}$ & Organic phase & $\%$ & 30 & 70 \\
2 & $X_{2}$ & Buffer $(\mathrm{pH})$ & Number & 4 & 6 \\
3 & $\mathrm{X}_{3}$ & Flow rate & $\mathrm{ml} / \mathrm{min}$ & 0.6 & 1 \\
\hline
\end{tabular}

\section{Method validation}

The method operable design region (MODR) constructed from contour plots controls the variations in the response [11, 28]. The optimized chromatographic method parameters were verified and validated as per standard guidelines [29-32].

\section{Specificity}

The spectra obtained from the synthetic mixture of standard solutions and commercial formulations were compared to assess the specificity of the method [33]. The chromatograms of blank, placebo, standard, and commercial formulations were examined to determine any additional peaks appearing at the retention time of sofosbuvir, velpatasvir, ledipasvir, and daclatasvir.

\section{Linearity and range}

Sofosbuvir aliquots of $0.6,1.2,1.8,2.4,3.0$, and $3.6 \mathrm{ml}$ were withdrawn from the stock solution $1000 \mu \mathrm{g} / \mathrm{ml}$ and were diluted to $10 \mathrm{ml}$ such that the final concentration of sofosbuvir is in the range of $60-360 \mu \mathrm{g} / \mathrm{ml}$. Velpatasvir and ledipasvir aliquots of $0.4,0.6,0.8,1.0,1.2$, and $1.4 \mathrm{ml}$ were withdrawn from their respective stock solution $1000 \mu \mathrm{g} / \mathrm{ml}$ and diluted to $10 \mathrm{ml}$ with diluent such that the final concentration of velpatasvir and ledipasvir was in the range of $40-140 \mu \mathrm{g} / \mathrm{ml}$. Daclatasvir aliquots of $0.2,0.4,0.6,0.8,1.0$, and $1.2 \mathrm{ml}$ were withdrawn from the stock solution $1000 \mu \mathrm{g} / \mathrm{ml}$ and diluted to $10 \mathrm{ml}$ with diluent such that the final concentration of daclatasvir in the range of $20-120 \mu \mathrm{g} / \mathrm{ml}$ was obtained; $20 \mu \mathrm{l}$ of each concentration was injected, and a calibration curve was plotted by taking peak area on the Y-axis and concentration of drug on the $\mathrm{X}$-axis.

\section{Accuracy}

The accuracy of the method was determined by spiking known concentration of standard drugs (80\%, $100 \%$, and $120 \%$ ) to their respective formulation three times in a sequence. The parameters like percent recovery and per cent relative standard deviation of all the four drugs were calculated accurately to justify the study.

\section{Precision}

The drugs sofosbuvir $(60,180$, and $360 \mu \mathrm{g} / \mathrm{ml})$, velpatasvir $(40,80$, and $140 \mu \mathrm{g} / \mathrm{ml})$, ledipasvir $(40,80$, and $180 \mu \mathrm{g} / \mathrm{ml})$, and daclatasvir $(20,60$, and $120 \mu \mathrm{g} / \mathrm{ml})$ were injected at each concentration level, and their peak areas were noted in triplicate on the same day and on three different days of the same week for intra- and inter-day precision studies. Parameters like per cent relative standard deviation in peak area and retention time of corresponding drug peaks were calculated as part of the validation. 
Table 2 System response of sofosbuvir, velpatasvir, ledipasvir, and daclatasvir in complete composite design

\begin{tabular}{lllllllll}
\hline S.No & Combination & $\begin{array}{l}\text { \% organic phase } \\
\mathbf{X}_{\mathbf{1}}\end{array}$ & $\begin{array}{l}\mathbf{p H} \\
\mathbf{X}_{\mathbf{2}}\end{array}$ & $\begin{array}{l}\text { Flow rate } \\
\mathbf{X}_{\mathbf{3}}\end{array}$ & $\begin{array}{l}\text { Theoretical } \\
\text { (sofosbuvir) }\end{array}$ & $\begin{array}{l}\text { Theoretical } \\
\text { (velpatasvir) }\end{array}$ & $\begin{array}{l}\text { Theoretical } \\
\text { (ledipasvir) }\end{array}$ & $\begin{array}{l}\text { Theoretical } \\
\text { (daclatasvir) }\end{array}$ \\
\hline 1 & 1 & 30 & 4.0 & 0.6 & $17,398.754$ & 921 & 955 & 934 \\
2 & $X_{1}$ & 70 & 4.0 & 0.6 & 2845.40 & 7132.22 & 4852.92 & 1506.5 \\
3 & $X_{2}$ & 30 & 6.0 & 0.6 & $19,215.652$ & 932 & 965 & 956 \\
4 & $X_{1} X_{2}$ & 70 & 6.0 & 0.6 & 8357.634 & 8403.91 & 5528.55 & 7649.63 \\
5 & $X_{3}$ & 30 & 4.0 & 1.0 & $12,942.93$ & 984 & 964.5 & 990 \\
6 & $X_{1} X_{3}$ & 70 & 4.0 & 1.0 & 2841.49 & 5047.30 & 3683.29 & 4144.34 \\
7 & $X_{2} X_{3}$ & 30 & 6.0 & 1.0 & $15,081.284$ & 989 & 978 & 949 \\
8 & $X_{1} X_{2} X_{3}$ & 70 & 6.0 & 1.0 & 5090.77 & 5660.94 & 3738.79 & 4541.39 \\
\hline
\end{tabular}

\section{LOD and LOQ}

From the linearity data, the limit of detection and quantification was calculated using the following formula.

$$
\begin{aligned}
& L O D=\frac{3.3 \sigma}{S} \\
& L O Q=\frac{10 \sigma}{S}
\end{aligned}
$$

where $\sigma$ is the standard deviation of the response, and $\mathrm{S}$ is the slope of the calibration curve of the analytes.

\section{Robustness}

To estimate the robustness of the experimental design, optimized chromatographic parameters like flow rate $( \pm$ $0.1 \mathrm{ml} / \mathrm{min}), \mathrm{pH}( \pm 0.2), \%$ organic phase $( \pm 2 \%)$, and wavelength $( \pm 2 \mathrm{~nm})$ were varied slightly in the method used for the analysis of samples containing sofosbuvir, velpatasvir, ledipasvir, and daclatasvir.

\section{Assay of marketed formulation}

The marketed formulations 20 tablets each of the respective drugs, EPCLUSA (sofosbuvir $400 \mathrm{mg}+$ velpatasivir $100 \mathrm{mg}$ ), HARVONI (sofosbuvir $400 \mathrm{mg}+$ ledipasivir $100 \mathrm{mg}$ ), and DARVONI (sofosbuvir $400 \mathrm{mg}$
+ daclatasivir $60 \mathrm{mg}$ ) were weighed, and average weight of each tablet was noted. An estimated quantity of powder equivalent to $50 \mathrm{mg}$ velpatasvir and $200 \mathrm{mg}$ sofosbuvir in EPCLUSA (520.88 mg), $50 \mathrm{mg}$ ledipasvir and 222 $\mathrm{mg}$ sofosbuvir in HARVONI $(579.21 \mathrm{mg})$, and $30 \mathrm{mg}$ of daclatasvir and $200 \mathrm{mg}$ of sofosbuvir in DARVONI (384.19 mg) was taken in $25 \mathrm{ml}$ volumetric flasks; $20 \mathrm{ml}$ of acetonitrile was added initially to all the flasks and sonicated for $15 \mathrm{~min}$; later, the flasks were brimmed up to the mark using acetonitrile to prepare stock solutions. The stock solutions were then filtered using Whatman filter paper (No: 41), and sample solutions were prepared by diluting $1: 10$ with diluents to obtain $200 \mu \mathrm{g} / \mathrm{ml}$ of velpatasvir and $800 \mu \mathrm{g} / \mathrm{ml}$ of sofosbuvir for Epclusa, $200 \mu \mathrm{g} /$ $\mathrm{ml}$ of ledipasvir and $888 \mu \mathrm{g} / \mathrm{ml}$ of sofosbuvir for HARVONI, and $120 \mu \mathrm{g} / \mathrm{ml}$ of daclatasvir and $800 \mu \mathrm{g} / \mathrm{ml}$ of sofosbuvir for DARVONI. Further dilution of sample solutions within a range of linearity was undertaken by taking $3 \mathrm{ml}$ of solution from respective volumetric flasks and making up to $10 \mathrm{ml}$ with diluents to obtain $60 \mu \mathrm{g} / \mathrm{ml}$ of velpatasvir and $240 \mu \mathrm{g} / \mathrm{ml}$ of sofosbuvir for EPCLUSA, $60 \mu \mathrm{g} / \mathrm{ml}$ of ledipasvir and $252 \mu \mathrm{g} / \mathrm{ml}$ of sofosbuvir for HARVONI, and $36 \mu \mathrm{g} / \mathrm{ml}$ of daclatasvir and $240 \mu \mathrm{g} / \mathrm{ml}$ of sofosbuvir for DARVONI

\begin{tabular}{|c|c|c|c|c|c|c|c|c|c|}
\hline \multirow[t]{2}{*}{ S.No } & \multirow[t]{2}{*}{ Combination } & \multicolumn{2}{|l|}{ Sofosbuvir } & \multicolumn{2}{|l|}{ Velpatasvir } & \multicolumn{2}{|l|}{ Ledipasvir } & \multicolumn{2}{|l|}{ Daclatasvir } \\
\hline & & Coefficient & SS ratio & Coefficient & SS ratio & Coefficient & SS ratio & Coefficient & SS ratio \\
\hline 1 & $b_{0}$ & $10,471.73$ & - & 3758.796 & - & 2708.256 & - & 2708.857 & - \\
\hline 2 & $b_{1}$ & -5687.915 & $85.8153 \%$ & 2802.296 & $90.1972 \%$ & 1742.631 & $90.942 \%$ & 1751.607 & $56.360 \%$ \\
\hline 3 & $b_{2}$ & 1464.595 & $5.6898 \%$ & 237.662 & $0.6488 \%$ & 94.328 & $0.2665 \%$ & 815.147 & $12.206 \%$ \\
\hline 4 & $b_{12}$ & 475.782 & $0.6004 \%$ & 233.662 & $0.6271 \%$ & 88.453 & $0.2343 \%$ & 819.897 & $12.348 \%$ \\
\hline 5 & $b_{3}$ & -1482.62 & $5.8307 \%$ & -588.4863 & $3.9778 \%$ & -367.111 & $4.036 \%$ & -52.675 & $0.051 \%$ \\
\hline 6 & $b_{13}$ & 664.927 & $1.1728 \%$ & -618.486 & $4.3936 \%$ & -372.736 & $4.1606 \%$ & -64.925 & $0.0774 \%$ \\
\hline 7 & $b_{23}$ & -367.687 & $0.3586 \%$ & -83.006 & $0.0791 \%$ & -77.078 & $0.1779 \%$ & -726.135 & $9.685 \%$ \\
\hline 8 & $b_{123}$ & -448.05 & 0.5325 & -81.506 & $0.0763 \%$ & -77.953 & $0.182 \%$ & -710.385 & $9.2702 \%$ \\
\hline
\end{tabular}

Table 3 Statistical optimization analysis of sofosbuvir, velpatasvir, ledipasvir, and daclatasvir

SS sum of squares 
Table 4 Central composite plan of anti-viral drugs

\begin{tabular}{|c|c|c|c|c|c|c|c|c|}
\hline \multirow[t]{2}{*}{ S.No. } & \multirow[t]{2}{*}{ Trials } & \multirow{2}{*}{$\begin{array}{l}\text { Organic phase } \\
X_{1}\end{array}$} & \multirow{2}{*}{$\begin{array}{l}\mathrm{pH} \\
\mathrm{X}_{2}\end{array}$} & \multirow{2}{*}{$\begin{array}{l}\text { Flow rate } \\
\mathrm{X}_{3}\end{array}$} & \multicolumn{4}{|c|}{ Responses (Sof + Vel + Led + Dac) } \\
\hline & & & & & $\mathrm{TP}_{1}$ & $\mathrm{TP}_{2}$ & $\mathrm{TP}_{3}$ & $\mathrm{TP}_{4}$ \\
\hline 1 & I & 30 & 4.0 & 0.6 & $17,398.754$ & 921 & 955 & 934 \\
\hline 2 & $x_{1}$ & 70 & 4.0 & 0.6 & 2845.40 & 7132.22 & 4852.92 & 1506.5 \\
\hline 3 & $x_{2}$ & 30 & 6.0 & 0.6 & $19,215.652$ & 932 & 965 & 956 \\
\hline 4 & $x_{1} x_{2}$ & 70 & 6.0 & 0.6 & 8357.634 & 8403.91 & 5528.55 & 7649.63 \\
\hline 5 & $x_{3}$ & 30 & 4.0 & 1.0 & $12,942.93$ & 984 & 964.5 & 990 \\
\hline 6 & $x_{1} x_{3}$ & 70 & 4.0 & 1.0 & 2841.49 & 5047.30 & 3683.29 & 4144.34 \\
\hline 7 & $x_{2} x_{3}$ & 30 & 6.0 & 1.0 & $15,081.284$ & 989 & 978 & 949 \\
\hline 8 & $x_{1} x_{2} x_{3}$ & 70 & 6.0 & 1.0 & 5090.77 & 5660.94 & 3738.79 & 4541.39 \\
\hline 9 & Mid-point & 50 & 5.0 & 0.8 & 8167.088 & 7808.8 & 1678.658 & 6681.036 \\
\hline 13 & $X_{1}-2 L$ & 10 & 5.0 & 0.8 & 591.83 & 491.08 & 521.66 & 738.19 \\
\hline 14 & $X_{1}+2 L$ & 90 & 5.0 & 0.8 & 5766.10 & 444.42 & 632.16 & 569.14 \\
\hline 15 & $X_{2}-2 L$ & 50 & 3.0 & 0.8 & 6269.09 & 4009.30 & 1688.17 & 1864.41 \\
\hline 16 & $X_{2}+2 L$ & 50 & 7.0 & 0.8 & 7678.7 & 3967.22 & 541.32 & 4069.66 \\
\hline 17 & $X_{3}-2 L$ & 50 & 5.0 & 0.4 & $10,603.02$ & 8545.68 & 3623.83 & 6023.1 \\
\hline 18 & $X_{3}+2 L$ & 50 & 5.0 & 1.2 & 5649.47 & 4589.46 & 1650.81 & 3099.35 \\
\hline
\end{tabular}

TP Theoretical plates

\section{Results}

\section{Preliminary studies}

Authentication of drugs was done by determination of melting point, UV absorption spectra $\left(\lambda_{\max }\right)$, and FTIR. The results of these studies were compared with the reference values and found to be within the limit of acceptance. The individual standard solutions $(10 \mu \mathrm{g} / \mathrm{ml})$ of four drugs in diluent (acetonitrile: water, 50:50 \% v/v) were analysed in a UV spectrophotometer ranging from 200 to $400 \mathrm{~nm}$. From the overlain spectrum of four drugs, the wavelength $260 \mathrm{~nm}$ was selected for estimation in order to get maximum responses for four analytes [29, 33].

\section{Screening studies}

The critical process parameters such as organic phase, aqueous phase $(\mathrm{pH})$, flow rate, wavelength, and interactions between the factors, which can affect the chromatographic responses such as theoretical plate number and retention time, were screened by using experimental design.

\section{AQbD approach method optimization}

In order to determine optimum chromatographic conditions, selected variables were screened using a factorial experimental design $\left(2^{3}\right)$. Software-designed experimental

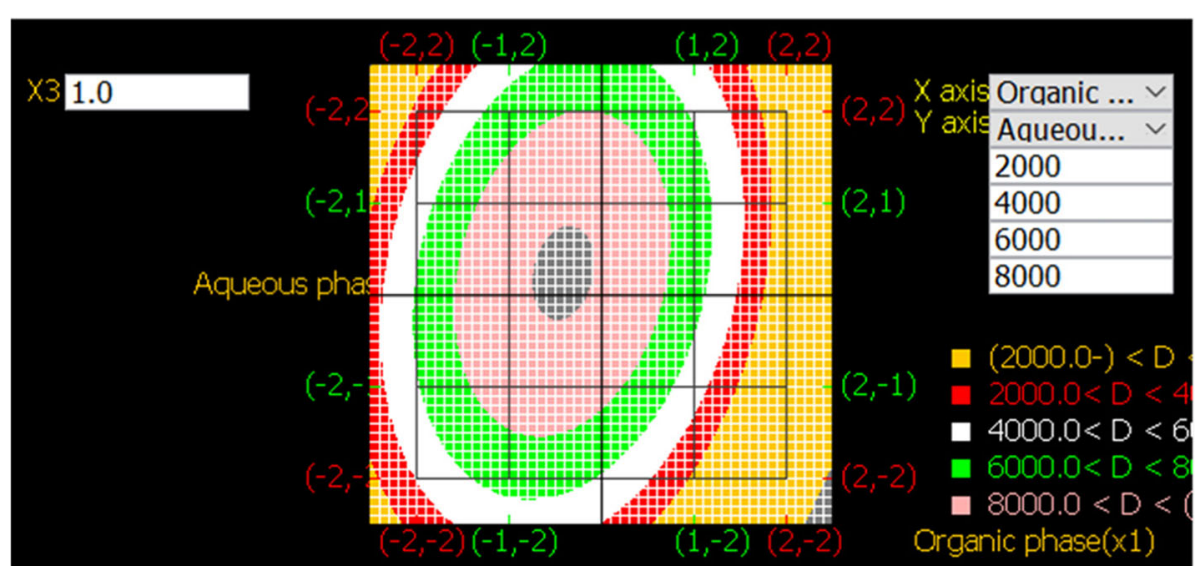

Fig. 1 Contour plot of sofosbuvir at $1.0 \mathrm{ml}$ flow rate 


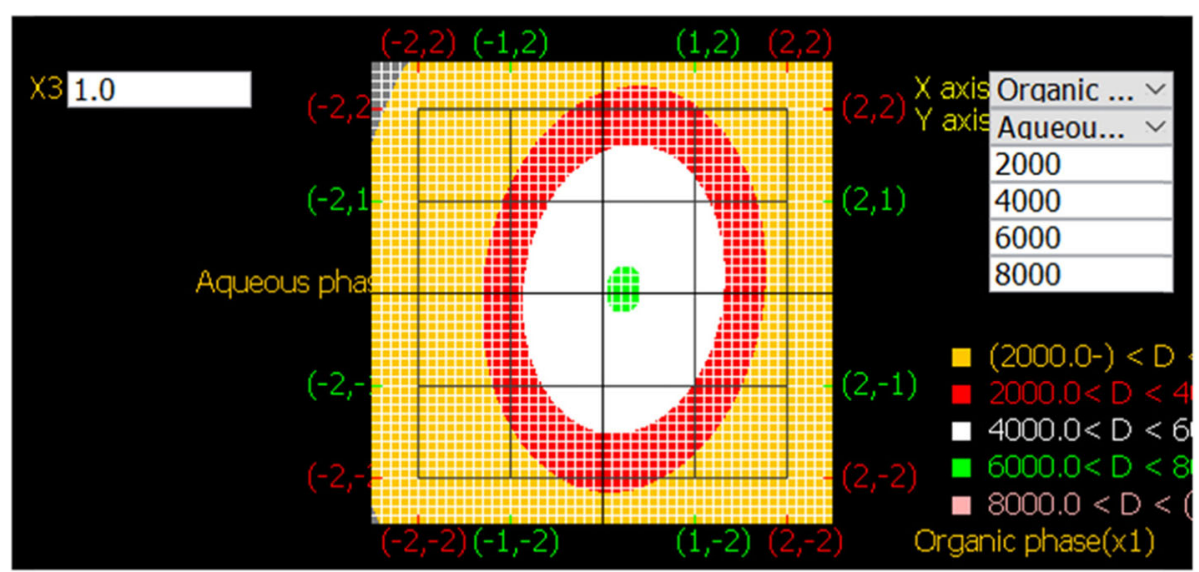

Fig. 2 Contour plot of velpatasvir at $1.0 \mathrm{ml}$ flow rate

trials were performed with respect to three variables such as \% organic phase $\left(\mathrm{X}_{1}\right)$, aqueous phase $\mathrm{pH}\left(\mathrm{X}_{2}\right)$,and flow rate $\left(\mathrm{X}_{3}\right)$ to obtain theoretical plate number as method control response for four drugs. The software suggested central composite experimental design (CCD) was evaluated for the effect of individual factors on the response in the form of a contour plot.

\section{Statistical analysis}

Statistical analysis of experimental observations was performed to evaluate significant factors that affect the chromatographic response and were tabulated in Tables 2 and 3. Polynomial equations for the prediction of responses were obtained as follows (Eqs. 1 to 4) for sofosbuvir, velpatasvir, ledipasvir, and daclatasvir.

$$
\begin{aligned}
\mathrm{Y}_{\mathrm{SOF}}= & 10471.73+(-5687) \mathrm{b}_{1}+(1464) \mathrm{b}_{2} \\
& +(475.782) \mathrm{b}_{12}+(-1482.62) \mathrm{b}_{3} \\
& +(-664.927) \mathrm{b}_{13}+(-367.687) \mathrm{b}_{23} \\
& +(-448.05) \mathrm{b}_{123}
\end{aligned}
$$

$$
\begin{aligned}
\mathrm{Y}_{\mathrm{VEL}}= & 3758.796+(2802.296) \mathrm{b}_{1}+(237.662) \mathrm{b}_{2} \\
& +(233.662) \mathrm{b}_{12}+(-588.486) \mathrm{b}_{3} \\
& +(-618.482) \mathrm{b}_{13}+(-83.006) \mathrm{b}_{23} \\
& +(-81.506) \mathrm{b}_{123} \\
\mathrm{Y}_{\mathrm{LED}}= & 2708.256+(1742.631) \mathrm{b}_{1}+(94.328) \mathrm{b}_{2} \\
& +(88.453) \mathrm{b}_{12}+(-367.111) \mathrm{b}_{3} \\
& +(-372.736) \mathrm{b}_{13}+(-77.078) \mathrm{b}_{23} \\
& +(-77.953) \mathrm{b}_{123} \\
& \\
\mathrm{Y}_{\mathrm{DAC}}= & 2708.857+(1751.607) \mathrm{b}_{1} \\
& +(815.147) \mathrm{b}_{2}+(819.897) \mathrm{b}_{12} \\
& +(-52.675) \mathrm{b}_{3}+(-64.925) \mathrm{b}_{13} \\
& +(-726.135) \mathrm{b}_{23}+(-710.385) \mathrm{b}_{123}
\end{aligned}
$$

(Y-response of respective drug; $b_{0}$-intercept; $b_{1}, b_{2}$, and $b_{3}$-regression coefficients of variables $X_{1}, X_{2}$, and $X_{3}$, respectively; $b_{12}, b_{13}$, and $b_{23}$-regression coefficients for two factor interactions between variables; and $b_{123}-$

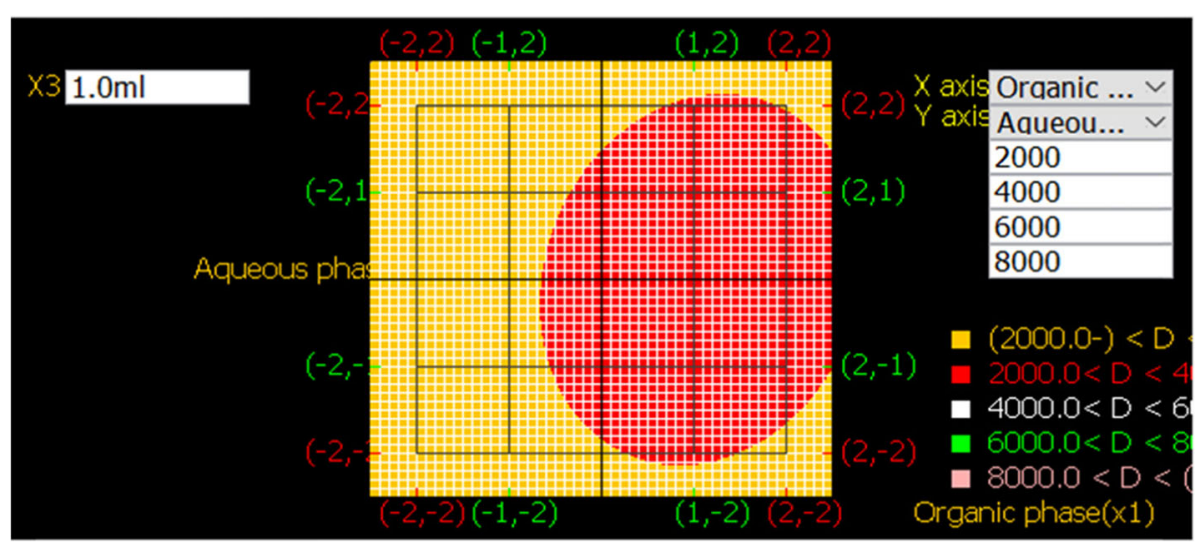

Fig. 3 Contour plot of ledipasvir at $1.0 \mathrm{ml}$ flow rate 


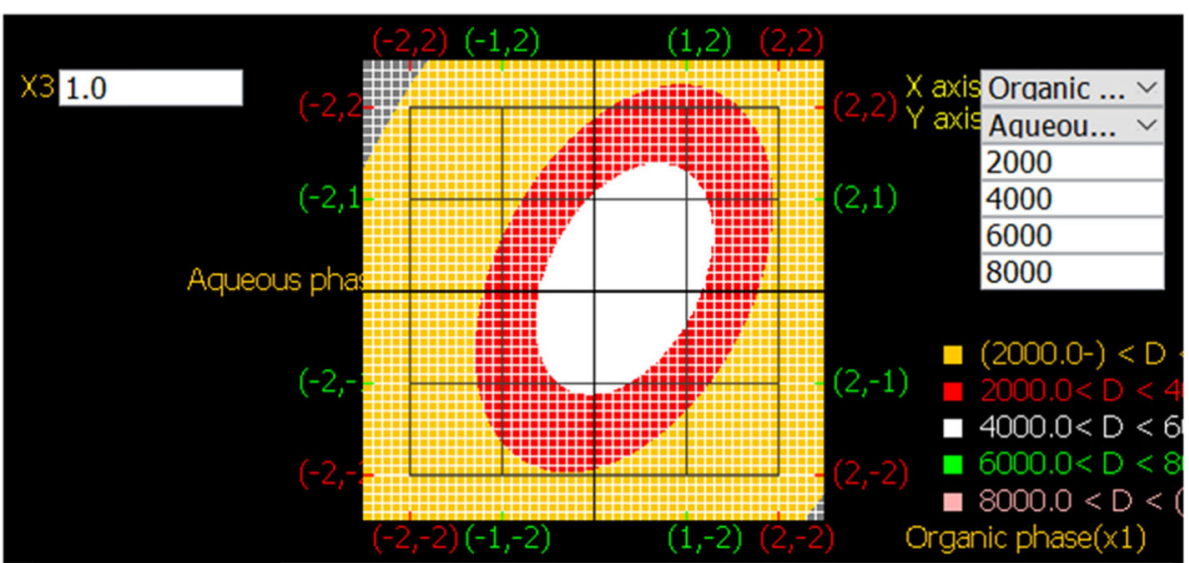

Fig. 4 Contour plot of daclatasvir at $1.0 \mathrm{ml}$ flow rate

coefficient for three factor interactions between three variables).

Statistical data analysis of sofosbuvir exhibited $\mathrm{X}_{1}$ (\% organic phase) as the significant factor owing to the highest SS ratio $(85.815 \%)$ at $b_{1}$ combination. The negative sign of the coefficient indicates that the lower the \% organic phase, the higher is the plate number of the chromatographic system. The next best SS ratio $(5.8307 \%)$ was obtained at $b_{3}$ combination, i.e. $\mathrm{X}_{3}$ variable, so the flow rate was also an important factor. The negative sign of the coefficient indicates that the lower the flow rate, the higher the response of the chromatographic system. The SS ratio (5.689\%) was obtained $a b_{2}$ combination, i.e. $\mathrm{X}_{2}$ variable, so the $\mathrm{pH}$ was also an important factor.

Statistical data analysis of velpatasvir, ledipasvir, and daclatasvir exhibited $\mathrm{X}_{1}$ (\% organic phase) as the significant factor owing to the highest SS ratios $(90.19 \%, 90.94 \%$, and $56.36 \%)$ at $b_{1}$ combination. The positive sign of the coefficient indicates that higher the \% organic phase in the mobile phase, the higher

Table 5 Optimized chromatographic conditions

\begin{tabular}{ll}
\hline Parameter/conditions & Description/values \\
\hline Column & XTERRA RP18 $(250 \times 4.6 \mathrm{~mm}, 5 \mu)$ \\
Detector & UV-Vis detector \\
Flow rate & $\mathbf{1 . 0} \mathbf{~ m L / m i n ~}$ \\
Injection volume & $20 \mu \mathrm{l}$ \\
Wavelength & $260 \mathrm{~nm}$ \\
Column temperature & $25^{\circ} \mathrm{C}$ \\
Run time & $15 \mathrm{~min}$ \\
Buffer & Phosphate buffer ( pH adjusted to 5.0) \\
Mobile phase & ACN: buffer (50:50) \\
Program & Isocratic \\
\hline
\end{tabular}

is the response (theoretical plates number) of the chromatographic system. The SS ratio of velpatasvir and ledipasvir $(4.39 \%$ and $4.16 \%)$ was obtained at $b_{13}$ combination, i.e.; $\mathrm{X}_{1} \mathrm{X}_{3}$ variable, so the interaction of $\%$ organic phase $\left(X_{1}\right)$ and flow rate $\left(X_{3}\right)$ has an influence on the chromatographic system. The negative sign of the coefficient indicates that the lower the interaction, the better the response of the chromatographic system. The SS ratio of daclatasvir (12.206\%) indicated $\mathrm{pH}$ as an influential factor.

Analysis of results (ANOVA) showed curvature effect was significant. The curvature effect showed a $95 \%$ confidence level. This indicates $X_{1}, X_{2}$, and $X_{3}$ along with interactions were highly significant at a 95\% confidence level. Hence, it is mandatory to select a central composite design. The central composite design of sofosbuvir, velpatasvir, ledipasvir, and daclatasvir with its responses (theoretical plate number) was reported in Table 4.

\section{Contour plot}

The method was optimized based on contour plots drawn by varying \% organic phase and $\mathrm{pH}$ keeping flow rate constant. The plots are as shown in Figs. 1, 2, 3, and 4. The \% organic phase has a prominent effect on theoretical plate number for the four drugs and indicates that organic modifier above +1 level (70\%) and below -1 level (30\%) decreases the response. The aqueous phase $(\mathrm{pH})$ of the mobile phase showed a significant effect on the four drugs and indicates that $\mathrm{pH}$ above +1 (7) and below -1 (4) decreases the response. Hence, \% organic phase at mid-level and the $\mathrm{pH}$ at a lower level can be preferred to reduce the cost of the experiment.

\section{Optimized experimental conditions}

To optimize the HPLC parameters, several mobile phase compositions, changes in $\mathrm{pH}$, and changes in flow rate 


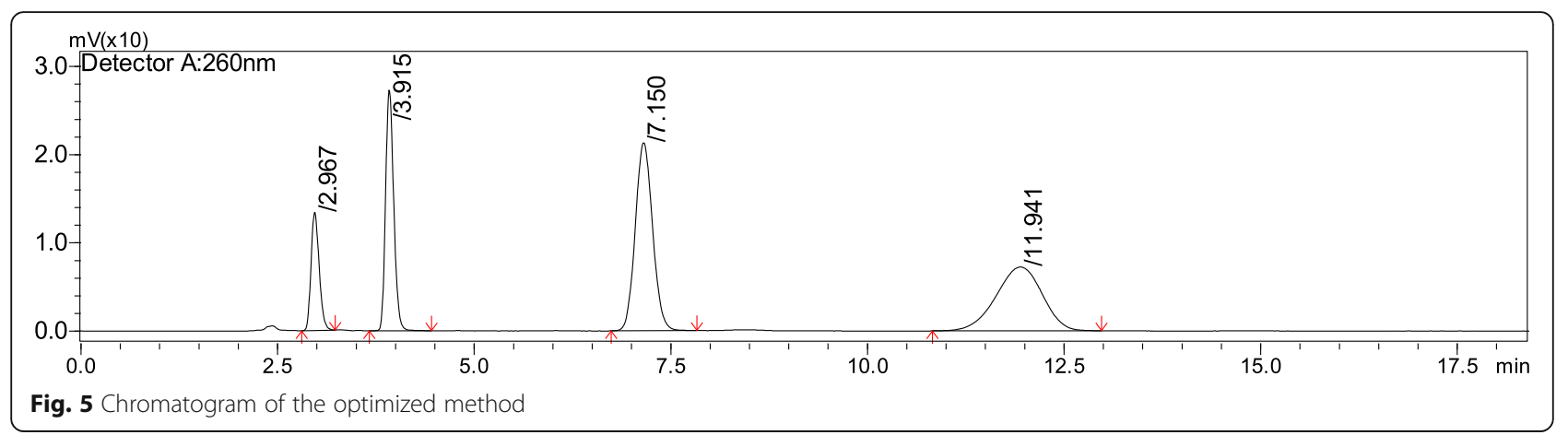

Table 6 Chromatographic results for the optimized method

\begin{tabular}{|c|c|c|c|c|c|c|c|}
\hline S.No & Name of the drug & Retention time & Area & HETP & Resolution & Tailing factor & Theoretical plates \\
\hline 1 & Daclatasvir & 2.96 & 96,858 & 42.97 & - & 1.26 & 3940.49 \\
\hline 2 & Sofosbuvir & 3.91 & 195,757 & 24.21 & 4.7 & 1.24 & 6194.80 \\
\hline 3 & Velpatasvir & 7.15 & 326,395 & 30.61 & 10.6 & 1.10 & 4899.29 \\
\hline 4 & Ledipasvir & 11.94 & 297,377 & 77.56 & 6.4 & 1.09 & 2115.98 \\
\hline
\end{tabular}

Table 7 Results of the method validation

\begin{tabular}{|c|c|c|c|c|c|}
\hline Parameter & & $\begin{array}{l}\text { Results of } \\
\text { sofosbuvir }\end{array}$ & $\begin{array}{l}\text { Results of } \\
\text { velpatasivir }\end{array}$ & $\begin{array}{l}\text { Results of } \\
\text { ledipasivir }\end{array}$ & $\begin{array}{l}\text { Results of } \\
\text { daclatasivir }\end{array}$ \\
\hline \multirow[t]{3}{*}{ Linearity } & Linearity range & $60-360 \mu \mathrm{g} / \mathrm{mL}$ & $40-140 \mu \mathrm{g} / \mathrm{mL}$ & $40-140 \mu \mathrm{g} / \mathrm{mL}$ & $20-120 \mu \mathrm{g} / \mathrm{mL}$ \\
\hline & $\begin{array}{l}\text { Correlation coefficient } \\
\left(R^{2}\right)\end{array}$ & 0.999 & 0.999 & 0.998 & 0.998 \\
\hline & Regression equation & $y=3276 x-44,583$ & $y=5226 x-95,804$ & $y=5089 x-90,670$ & $y=3500 x+20,863$ \\
\hline \multirow[t]{2}{*}{ Sensitivity } & $\operatorname{LOD}(\mu \mathrm{g} / \mathrm{ml})$ & 1.389 & 0.082 & 0.622 & 0.772 \\
\hline & LOQ $(\mu \mathrm{g} / \mathrm{ml})$ & 4.167 & 0.246 & 1.866 & 2.316 \\
\hline \multirow[t]{2}{*}{ Precision (\% RSD of peak area) } & Intra-day precision & 0.303 & 0.953 & 0.893 & 0.836 \\
\hline & Inter-day precision & 0.566 & 0.99 & 0.92 & 0.956 \\
\hline \multirow{4}{*}{$\begin{array}{l}\text { Robustness (\% RSD of peak } \\
\text { area) }\end{array}$} & Flow rate $( \pm 0.1 \mathrm{ml} / \mathrm{min})$ & 0.63 & 0.336 & 0.163 & 1.13 \\
\hline & $\mathrm{pH}( \pm 0.2)$ & 0.896 & 0.406 & 0.16 & 1.32 \\
\hline & Organic phase $( \pm 1 \%)$ & 0.62 & 0.34 & 0.15 & 1.2 \\
\hline & Wavelength ( $\pm 2 \mathrm{~nm})$ & 0.623 & 0.37 & 0.303 & 1.53 \\
\hline \multirow[t]{4}{*}{ System suitability } & Retention time (min) & 3.91 & 7.15 & 11.94 & 2.96 \\
\hline & $\begin{array}{l}\text { Theoretical plate } \\
\text { number }\end{array}$ & 6194.8 & 4899.29 & 2113.99 & 3940.49 \\
\hline & Tailing factor & 1.24 & 1.10 & 1.13 & 1.26 \\
\hline & Resolution & 4.7 & 10.6 & 6.4 & - \\
\hline
\end{tabular}


Table 8 Assay of the marketed formulations

\begin{tabular}{|c|c|c|c|c|c|c|c|c|}
\hline \multirow[t]{2}{*}{ Formulation } & \multicolumn{4}{|l|}{ Sofosbuvir } & \multicolumn{4}{|c|}{ Velpatasvir/ledipasvir/daclatasvir } \\
\hline & $\begin{array}{l}\text { Label claim } \\
\text { (mg) }\end{array}$ & $\begin{array}{l}\text { Amount found (mg) (A.M } \\
\pm \text { SD) }\end{array}$ & $\begin{array}{l}\% \\
\text { assay }\end{array}$ & $\begin{array}{l}\% \\
\text { RSD }\end{array}$ & $\begin{array}{l}\text { Label claim } \\
\text { (mg) }\end{array}$ & $\begin{array}{l}\text { Amount found (mg) (A.M } \\
\pm \text { SD) }\end{array}$ & $\begin{array}{l}\% \\
\text { assay }\end{array}$ & $\begin{array}{l}\% \\
\text { RSD }\end{array}$ \\
\hline $\begin{array}{l}\text { ECLUPSA (SOF + } \\
\text { VEL) }\end{array}$ & 400 & $410.8 \pm 1.23$ & 102.7 & 0.29 & 100 & $102.3 \pm 0.59$ & 100.2 & 0.57 \\
\hline $\begin{array}{l}\text { HARVONI (SOF + } \\
\text { LED) }\end{array}$ & 400 & $408 \pm 1.49$ & 102 & 0.36 & 90 & $89.09 \pm 0.25$ & 98.9 & 0.28 \\
\hline $\begin{array}{l}\text { DARVONI (SOF + } \\
\text { DAC) }\end{array}$ & 400 & $409.2 \pm 1.56$ & 102.3 & 0.38 & 60 & $61.05 \pm 0.45$ & 101.75 & 0.73 \\
\hline
\end{tabular}

A.M arithmetic mean, $S D$ standard deviation, $\% R S D$ relative standard deviation

were attempted. A satisfactory separation of the drugs was obtained by XTERRA RP18 $(250 \times 4.6 \mathrm{~mm}, 5 \mu)$ column eluted with acetonitrile and potassium dihydrogen phosphate buffer of pH 5.0 in the ratio of 50 : $50 \% \mathrm{v} / \mathrm{v}$ by isocratic elution pattern at a flow rate of $1.0 \mathrm{ml} / \mathrm{min}$ with a detection wavelength of $260 \mathrm{~nm}$ for sofosbuvir, velpatasvir, ledipasvir, and daclatasvir. of trial methods were as shown in Fig. 5, and its peak results were reported in Table 6 .

\section{Method validation}

The method was optimized and validated according to ICH Q2 (R1) [32] guidelines. A linear response was

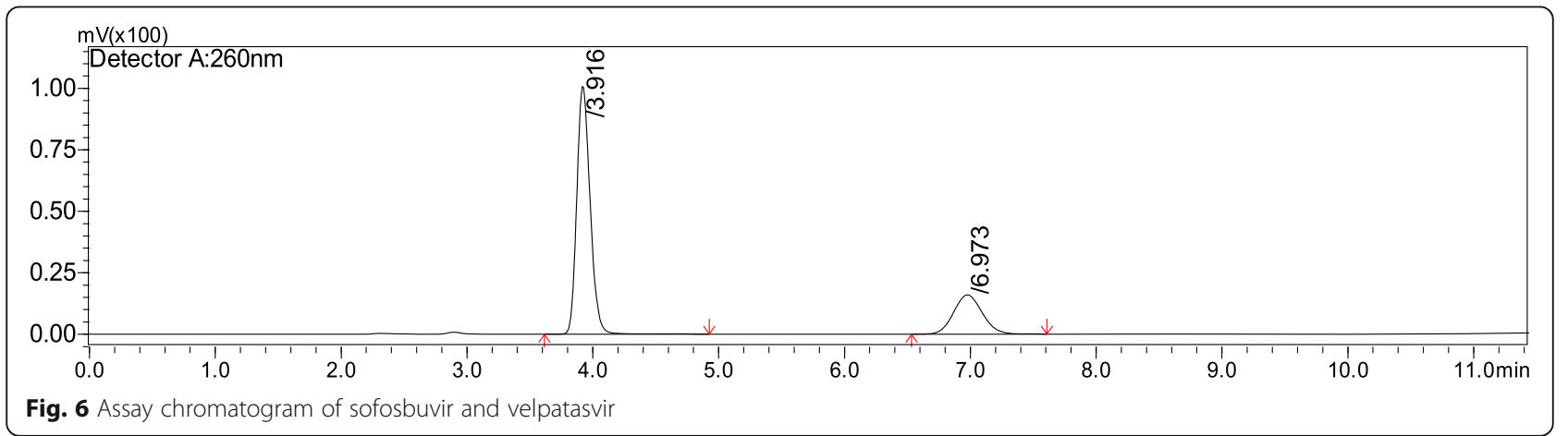

The injection volume of $20 \mu \mathrm{l}$ at $25^{\circ} \mathrm{C}$ temperature afforded the best separation of these analytes. The retention time was found to be $2.96 \mathrm{~min}$ for daclatasvir, $3.91 \mathrm{~min}$ for sofosbuvir, $7.15 \mathrm{~min}$ for velpatasvir, and $11.94 \mathrm{~min}$ for ledipasvir. The optimized method conditions were shown in Table 5 . The chromatograms willful over the examined concentration range of 60 $360 \mu \mathrm{g} / \mathrm{ml}$ for sofosbuvir, $40-140 \mu \mathrm{g} / \mathrm{ml}$ for velpatasvir, $40-140 \mu \mathrm{g} / \mathrm{ml}$ for ledipasvir, and $20-120 \mu \mathrm{g} / \mathrm{ml}$ for daclatasvir. Chromatograms of blank and placebo had a dearth of the peak at the retention time of title drugs indicated the specificity of the method. The accuracy of

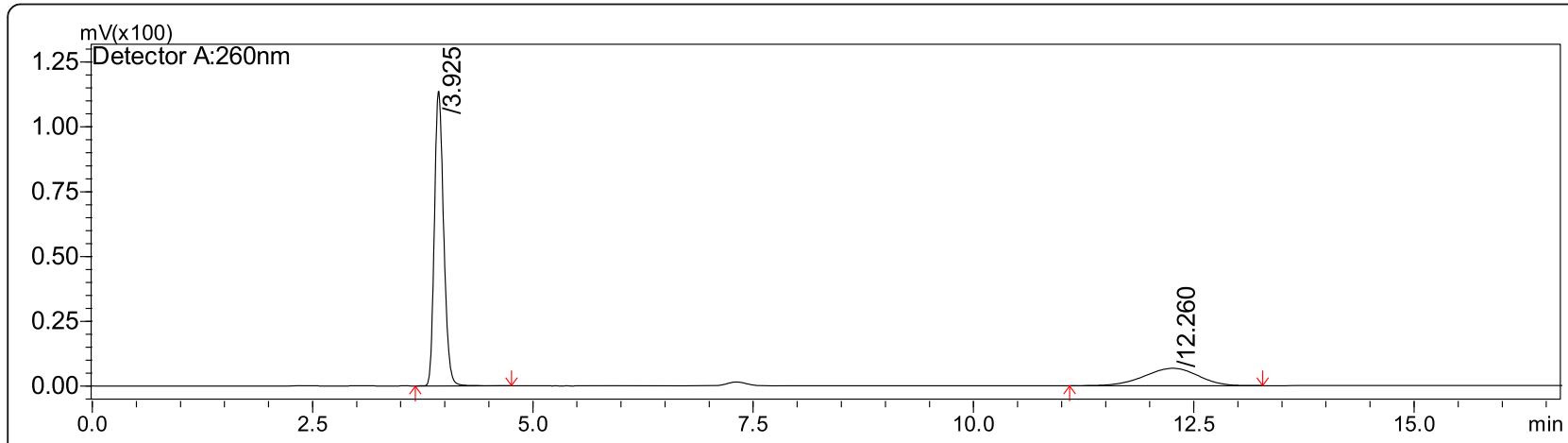

Fig. 7 Assay of sofosbuvir and ledipasvir 


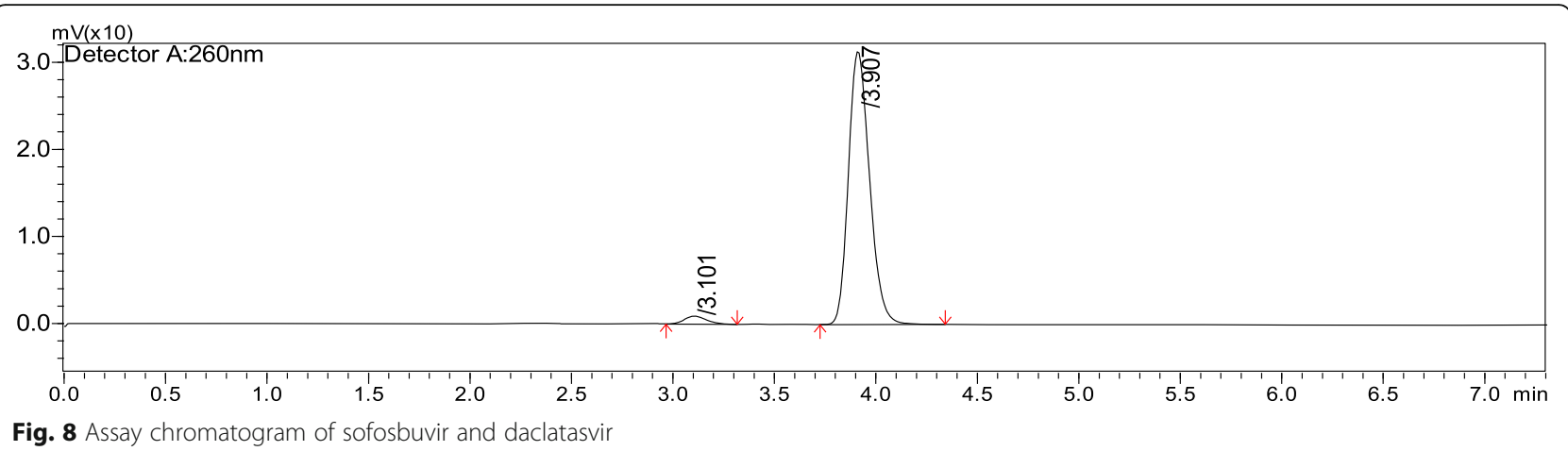

the method was validated by recovery studies and was found to be significant under specification limits, with afforded recovery of $98.8-101 \%$ for sofosbuvir, $99-102 \%$ for velpatasvir, $97-105 \%$ for ledipasvir, and $96-105 \%$ for daclatasvir. The \% RSD values for intra-day and interday precision were less than 2.0, which endorsed the good repeatability of the proposed method. Predicted response of optimized method parameters in the robust process (MODR of contour plot) was verified experimentally, and no significant change in retention time, peak area, and tailing factor and plate count by deliberate variations in method parameters was observed. The results of the system suitability test and validation were represented in Table 7 .

\section{Assay of marketed dosage form}

The proposed method was evaluated by the assay of commercially available tablet dosage forms. The results obtained were compared with the corresponding labelled amounts and reported in Table 8 . The \% assay results of sofosbuvir and velpatasvir in EPCLUSA was found to be $102.7 \%$ and $100.2 \%$, sofosbuvir and ledipasvir in HARVONI found to be $102 \%$ and $98.9 \%$, and \% assay of sofosbuvir and daclatasvir in DARVONI was found to be $102 \%$ and $101.7 \%$, respectively. The $\%$ RSD was less than 2 , which indicates the accuracy of the proposed method. The assay chromatograms of respective drugs were shown in Figs. 6, 7, and 8, respectively.

\section{Discussion}

The rising need for multi-drug anti-viral therapy shapes novel challenges in analytical research. The complexity in separating the drugs with different physico-chemical properties from the quaternary mixtures and applying them to the pharmacokinetic study was eased by AQbD. The research mainly focused on developing a method that has very little run time in just 16 experimental trials, which makes it more sustainable. The statistical outcomes also granted excellent linearity and specificity. The merits of the method such as low LOQ, high resolution, and good theoretical plate number compared to some peer journals [21-24] suggest its use for in vitro and in vivo characterization of novel formulation and in quality control. The central composite design suggested an increase in flow rate to obtain high resolution, and acidic $\mathrm{pH}$ in separating the basic components is good due to their more likeliness for protonation/ionization. The method catches its credibility by showing a resolution $(>2)$, tailing factor (0.9-1.2), capacity factor (1$10)$, number of theoretical plates ( $>2000)$, and very good HETP.

\section{Conclusion}

To our present knowledge no trials have been made yet to assay all four anti-viral drugs in a mixture. So, the robust, reproducible, sensitive, specific, inexpensive analytical method for simultaneous assessment of anti-viral drugs in co-formulated dosage forms has been developed using a central composite design. The proposed single (low consumption of solvent) analytical method can be employed for routine quality control analysis and pharmacokinetics studies of combined anti-viral drugs of sofosbuvir/velpatasvir, sofosbuvir/ledipasvir, and sofosbuvir/daclatasvir simultaneously.

\section{Abbreviations}

AQbD: Analytical quality by design; HPLC: High-performance liquid chromatography; MODR: Method operable design region; ICH: International Conference on Harmonization; RSD: Relative standard deviation; SOF: Sofosbuvir; VEL: Velpatasvir; LED: Ledipasvir; DAC: Daclatasvir; ATP: Analytical target profile; CMP: Critical method parameters; SS: Sum of squares; CQA: Critical quality attributes; HETP: Height equivalent to a theoretical plate

\section{Acknowledgements}

The authors are thankful to Hetero Drugs PVT Limited for rendering the gift samples of drugs and Gokaraju Rangaraju College of Pharmacy and Sir C.R. Reddy College of Pharmaceutical Sciences for providing the facilities to carry out this research.

\section{Authors' contributions}

Conception and design of the study were done by RTJ under the guidance of PDA and PRA. RTJ played a prominent role in the acquisition of the data. Analysis and/or interpretation of the data were taken care of by RTJ and PDA. Drafting of the manuscript was the job taken by RTJ. PDA revised the manuscript critically for important intellectual content. The version of the manuscript to be published was read and approved by all the contributing authors. 


\section{Funding}

Self-funded.

\section{Availability of data and materials}

Data and materials are available upon request.

\section{Declarations}

\section{Ethics approval and consent to participate}

Not applicable.

\section{Consent for publication}

Not applicable.

\section{Competing interests}

The authors declare that they have no competing interests.

\section{Author details}

${ }^{1}$ University College of Pharmaceutical Sciences, Acharya Nagarjuna University, Guntur, Andhra Pradesh 522510, India. ${ }^{2}$ Gokaraju Rangaraju College of Pharmacy, Department of Pharmaceutical Analysis, Osmania University, Hyderabad, Telangana 500090, India.

Received: 13 December 2020 Accepted: 18 May 2021 Published online: 27 May 2021

\section{References}

1. Arts EJ, Hazuda DJ (2012) HIV-1 antiretroviral drug therapy. Cold Spring Harb Perspect Med 2(4):1-23. https://doi.org/10.1101/cshperspect.a007161

2. Vidaltamayo R (2016) History and progress of antiviral drugs: from acyclovir to direct-acting antiviral agents (DAAs) for hepatitis C. Medicinia Universitaria 17(68):165-174. https://doi.org/10.1016/j.rmu.2015.05.003

3. Libby AM, Fish DN, Hosokawa PW, Linnebur SA, Metz KR, Nair KV, Saseen JJ, Vande Griend JP, Vu SP, Hirsch JD (2013) Patient-level medication regimen complexity across populations with chronic disease. Clin Ther 35(4):385-398. https://doi.org/10.1016/j.clinthera.2013.02.019

4. Lawitz E, Mangia A, Wyles D, Rodriguez-Torres M, Hassanein T, Gordon SC, Schultz M, Davis MN, Kayali Z (2013) Sofosbuvir for previously untreated chronic hepatitis C infection. N Engl J Med 368(20):1878-1887. https://doi. org/10.1056/nejmoa1214853

5. Link JO, Taylor JG, Xu L, Mitchell M, Guo H, Liu H, Kato D, Kirschberg T, Sun J, Squires N, Parrish J, Keller T, Yang Z, Yang C, Matles M, Wang Y, Wang K, Cheng G, Tian Y, Mogalian E, Mondou E, Cornpropst M, Perry J, Desai MC (2013) Discovery of ledipasvir (GS-5885): a potent, once-daily oral NS5A inhibitor for the treatment of hepatitis C virus infection. J Med Chem 57(5): 2033-2046. https://doi.org/10.1021/jm401499

6. Jackson WE, Everson GT (2017) Sofosbuvir and velpatasvir for the treatment of hepatitis C. Expert Rev Gastroenterol Hepatol 11(6):501-505. https://doi. org/10.1080/17474124.2017.1326817

7. Feld JJ, Jacobson IM, Asselah T, Ruane PJ, Gruener N, Abergel A, Mangia A, Mazzotta F, Moreno C, Yoshida E, Shafran SD, Towner WJ, Tran TT, Mcnally J, Osinusi A, Svarovskaia E, Zhu Y, Brainard DM, Mchutchison JG, Agarwal K, Zeuzem S (2015) Sofosbuvir and velpatasvir for HCV genotype 1, 2, 4, 5, and 6. N Engl J Med 373(27):2599-2607. https://doi.org/10.1056/nejmoa1512610

8. Smith MA, Regal RE, Mohammad RA (2016) Daclatasvir: a NS5A replication complex inhibitor for hepatitis C infection. Ann Pharmacother 50(1):39-46. https://doi.org/10.1177/1060028015610342

9. Raman NWSS, Mallu UR, Bapatu HR (2015) Analytical quality by design approach to test method development and validation in drug substance manufacturing. J Chemother 2015(Article Id-435129):1-8. https://doi.org/1 $0.1155 / 2015 / 435129$

10. Peraman R, Bhadraya K, Reddy YP (2015) Analytical quality by design: a tool for regulatory flexibility and robust analytics. Int J Anal Chem 2015(Artcle Id868727):1-9. https://doi.org/10.1155/2015/868727

11. Sandhu PS, Beg S, Katare OP, Singh B (2016) QbD-driven development and validation of a HPLC method for estimation of tamoxifen citrate with improved performance. J Chromatogr Sci 54(8):1373-1384. https://doi.org/1 0.1093/chromsci/bmw090

12. Bhutani $H$, Kurmi $M$, Singh S (2014) Quality by design (QbD) in analytical sciences: an overview. Pharma Times 46(8):71-75
13. Bajaj M, Nanda S (2018) Analytical quality by design (AQbD): new paradigm for analytical method development. Int J Dev Res 5(2):3589-3599

14. Vera L, De Zan MM, Cámara MS, Goicoechea C (2014) Talanta experimental design and multiple response optimization. Using the desirability function in analytical methods development. Talanta 124:123-138. https://doi.org/1 0.1016/j.talanta.2014.01.034

15. Singh B, Kapil R (2014) Developing drug delivery systems via modern DoE approaches. Chronicle Pharmabiz 10(1):30-32

16. Sangshetti JN, Deshpande M, Arote R, Zaheer Z, Shinde DB (2014) Quality by design approach: regulatory need. Arab J Chem 10(2):S3412-S3425. https://doi.org/10.1016/j.arabjc.2014.01.025

17. Hoffman M (2010) PAT: a new dawn for drug product quality. Pharmtech 5(2):52-59

18. Karmarkar S, Garbe R, Genchanok Y, George S, Yang X, Hammond R (2011) Quality by design (QbD) based development of a stability indicating HPLC method for drug and impurities. J Chromatogr Sci 49(6):439-446. https:// doi.org/10.1093/chrsci/49.6.439

19. Lloyd DK, Bergum J (2014) Application of quality by design (QbD) to the development and validation of analytical methods. In: Christopher MR (ed) Specification of drug substances and products: development and validation of analytical methods. Camridge: Elseiver. pp 29-72. https://doi.org/10.1016/ B978-0-08-098350-9.00003-5

20. Rote AP, Alhat J, Kulkarni AA (2017) Development and validation of RPHPLC method for the simultaneous estimation of ledipasvir and sofosbuvir in bulk and pharmaceutical dosage form. Int J Pharm Sci Drug Res 9(6):291298. https://doi.org/10.25004/IJPSDR.2017.090602

21. Rani JS, Devanna N (2017) A new RP-HPLC method development and validation for simultaneous estimation of sofosbuvir and velpatasvir in pharmaceutical dosage form. IJETSR 4(11):145-152

22. Zaman B, Siddique F, Hassan W (2016) RP - HPLC method for simultaneous determination of sofosbuvir and ledipasvir in tablet dosage form and its application to in vitro dissolution studies. Chromatographia. https://doi. org/10.1007/s10337-016-3179-9

23. Nagaraju T, Vardhan SVM, Kumar DR, Ramachandra D (2017) A new RPHPLC method for the simultaneous assay of sofosbuvir and ledipasvir in combined dosage form. Int J Chem Tech Res 10(7):761-768

24. Farid NF, Abdelwahab NS (2017) Chromatographic analysis of ledipasvir and sofosbuvir: new treatment for chronic hepatitis $C$ infection with application to human plasma. J Liq Chromatogr Relat Technol 40(7):327-332. https:// doi.org/10.1080/10826076.2017.1298526

25. Eldin AS, Azab SM, Shalaby A, El-maamly M (2017) The development of a new validated HPLC and spectrophotometric methods for the simultaneous determination of daclatasvir and sofosbuvir: antiviral drugs. Aust J Pharm 1(1):28-42. https://doi.org/10.26502/jppr.0004

26. Benzil D, Ramachandraiah C, Devanna N (2017) Analytical method development and validation for the simultaneous estimation of sofosbuvir and daclatasvir drug product by RP-HPLC method. Indo American J Pharm Res 7(7):2-9

27. Molnár l, Rieger H, Monks KE (2010) Aspects of the "design space" in high pressure liquid chromatography method development. J Chromatogr A 1217(19):3193-3200. https://doi.org/10.1016/j.chroma.2010.02.001

28. Awotwe-otoo D, Agarabi C, Faustino PJ, Habib MJ, Lee S, Khan MA, Shah RB (2012) Application of quality by design elements for the development and optimization of an analytical method for protamine sulfate. J Pharm Biomed Anal 62:61-67. https://doi.org/10.1016/j.jpba.2012.01.002

29. Ravisankar P, Navya CN, Pravallika D, Sri DN (2015) A review on step-by-step analytical method validation. IOSR J Phar 5(10):7-19

30. Chauhan A, Mittu B, Chauhan P (2015) Analytical method development and validation: a concise review. J Anal Bioanal Tech 6(1):1-5. https://doi.org/1 $0.4172 / 2155-9872.1000233$

31. Carr GP, Wahlich JC (1990) A practical approach to method validation in pharmaceutical analysis. J Pharm Biomed Anal 8(8):613-618. https://doi. org/10.1016/0731-7085(90)80090-C

32. ICH, Q2 (R1) (2005) Validation of analytical procedures: text and methodology International Conference on Harmonization

33. Pavia DL, Lampman GM, Kriz GS (2001) Introduction to spetroscopy, 3rd edn. Thomson learning, Washington

\section{Publisher's Note}

Springer Nature remains neutral with regard to jurisdictional claims in published maps and institutional affiliations. 